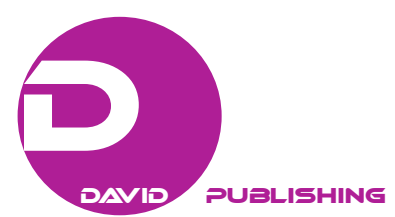

\title{
HRM, Organizational Psychology and Personnel Psychology: Linear and Simplex Analysis of HR
}

\author{
Gürhan Uysal \\ Ondokuz Mayis University, Samsun, Turkey
}

\begin{abstract}
Resarch topic of paper is lienar and simplex analysis in human resource management field. Research questions are quantitative models may increase effeciency of HR professionals, and mission of HRM field is to develop positive organizational psychology in employees. Organizational psychology is important research field in British academy. Further, simplex methodolohy is presented by G. B. Dantzig after World War II in order to solve linear programming. First of all, goal function is established in simplex, which is to maximize firm performance in this paper. Secondly, limits of problem are determined. Main limits in applying HRM in organizations might be HR professionals and top management. For example, SHRM (Society for Human Resource Management) of USA organizes programs for increading competency of HR professionals. Further, top management may impede on effectively applying HRM in organizations. Therefore, both of them may establish limits of simplex function. Research methods of study cover in-depth literature review in HRM field, and study has qualitative research dimension. Data analysis reveals that HRM may consist of three figures: they are individual performance, talent management, and organizational psychology. To conclude, HRM is appled in organizations to develop individual performance, talent management, and organizational psychology.
\end{abstract}

Keywords: renaissance, scientific revolution, HRM, theory, HR professionals, performance

\section{Introduction}

There are three eras in EU history: 15th century, 17th century, and 19th century. It witnessed renaissance in 15th century and witnessed scientific revolution in 17th century. Most probably, Renaissance Movements resulted in scientific revolution in 17th century. EU encouraged industrial revolution during 19th century. Thus, scientific revolution encouraged Industrial Revolution in 19th century. Chronology might be: renaissance, science, and industry. In addition, industrial and scientific revolution encouraged democracy in Europe as it appeared in 1789 in France.

Most recent topic for HRM might become "task performance". Because organizations consist of many organizational tasks. Task performance is related with competency and strategic human resource management. For example, SHRM, USA, increases competency of HR professionals. Americans call competency and task as human capital. For competence and task performance, employees must have theoretical knowledge, and they need to gain experience timely at work. Because if task performance of employees is higher, performance of

Gürhan Uysal, professor, Ph.D., School of Business, Ondokuz Mayis University, Samsun, Turkey.

Correspondence concerning this article should be addressed to Gürhan Uysal, School of Business, Ondokuz Mayis University, Kurupelit Campus, 55139 Atakum-Samsun, Turkey. 
their departmant increases. So, all departments come together, and have an impact on organizational performance. This is related with strategic human resource management (strategic HRM). Strategic HRM is maybe related with individual performance - firm performance relationship. If employees have high individual performance (task performance), firm performance may increase through department's performance. Therefore, HRM aims to increase task performance of employees.

Simplex is introduced by Dantzig in 1947. It is used for solving linear programs. In linear, there is only goal function, maximization, or minimization. For simplex, limits are included in problem solving.

\section{Theory}

HRM is maybe explained in organizations with individual performance, talent management, and organizational psychology (or personnel psychology). Objective of HRM might be to increase individual performance at work (that policy may be named as task performance policy). Therefore, goal function is set through HRM practices, talent management, and organizational psychology. Assumption is that organizations apply HRM practices to increase individual performance. Goal $(\mathrm{Z})$ is to increase firm performance. Therefore, HRM may be figured with three dimension: performance, talent management, and organizational psychology.

\section{Research Methods}

Findikci (2012) studied for behavioral sciences in academy. Further, Ulucan (2007) mentioned for quantitative models in firm's operations. In-depth literature review was implemented for this study. Quantitative methods began in business in 1920s by linear programming, and it is strenghtened after World War II such as presentation of program evaluationand review technic (PERT), critical path method (CPM) technics, and simplex analysis. Industrial Revolution started in Europe during 19th century, it may be described with factory production, and USA becomes frontier in industry after the World War II.

\section{Research Results: Linear and Simplex of HR}

Main result of this study is that quantitative methods may be applied for HRM and other fields in business. For example, Uysal $(2014 ; 2015)$ applied simplex methods for talent management, and applied decision tree analysis for human resource management practices.

Therefore, goal function of linear programming might be:

$$
\begin{gathered}
\text { Goal }(\mathrm{Z})=(2 \mathrm{HRM} 1+2 \mathrm{HRM} 2+2 \mathrm{HRM} 3+\mathrm{HRM} 4)+1 / 4 \text { talent management }(\mathrm{TM}) \\
+ \text { organizational psychology }(\mathrm{OP})
\end{gathered}
$$

so:

$$
\text { goal }(Z)=2 \mathrm{HRM}+1 / 4 \mathrm{TM}+\mathrm{OP}
$$

In this goal function, goal $(Z)$ is to heighten firm performance; and HRM $=$ HRM practices, $T M=$ Talent Management, and OP = Organizational Psychology. Assumption of study is that HRM practices and talent management and organizational psychology have an impact on firm performance. Continued, 2, 1/4, and 1 are coefficients of variables. HRM1, HRM2, HRM3, and HRM4 represent HRM practices applied in organizations.

Secondly, a firm may establish matrice structure of HRM. Matrix includes variables as HRM practices (Figure 1): 


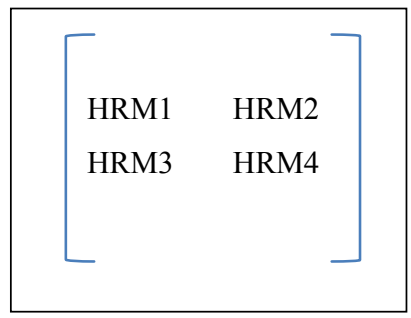

Figure 1. HR matrix.

In this HRM matrice, assumption, HRM1 = staffing, HRM2 = training, HRM3 = compensation, and HRM4 = performance appraisal.

In matrix structure, it is important to determine determinant for effectiveness. Objective of HRM is to achieve firm performance. Determinant of matrix may be performance appraisal. Because performance appraisal determines top performers and talents (i.e., stars employees).

Thirdly, limits of simplex fuction are: X1 = HR professionals, and X2 = Top Management. Because HR professionals make HRM effectively apply in organization, and top management may impede on HRM effectively applying in organizations. So, limit functions are as following:

$$
\begin{aligned}
& X 1+X 2 \geq 1 \\
& X 1+X 2 \geq 2
\end{aligned}
$$

and simplex table is established below (Figure 2):

\begin{tabular}{|c|c|c|c|c|c|}
\hline goal & $\mathrm{X} 1$ & $\mathrm{X} 2$ & $\mathrm{~S} 1$ & $\mathrm{~S} 2$ & \\
\hline $\mathrm{X} 1$ & 1 & 1 & 1 & 0 & 1 \\
\hline $\mathrm{X} 2$ & 1 & 1 & 0 & 1 & 2 \\
\hline & & & & & $?$ \\
\hline
\end{tabular}

Figure 2. Simplex table.

Accordingly, firms achieve optimal end when all variables in below line become positive, and question box (?) represents optimal solution.

\section{Analysis or Discussion: Fourth Industrial Revolution}

Modern economy currently struggles for the fourth Industrial Revolution (IR). The first is made by England and Europe in 1800s; the second appeared on economy in 1900s with electric and automobiles; the third may be described with computer sciences.

The Fouth IR may be described with intellectual capital. Competition between firms is strong in markets. There are lots of products in markets, and products are similar to each other. Customers have product choice dilemma. That dilemma may be called as isomorphism. What policy a firm may pursue under isomorphism threat? Answer might become human resources or intellectual capital. American HRM calls personnel or workforce as "human capital". Thus, intellectual capital may increase competitive advantage of company. Because intellectual capital may differentiate firm from rivals.

\section{Conclusion}

To conclude, firms apply HRM in their organizations via HRM practices (Bingol, 2014). Because HRM may have impact on firm performance through individual performance and talent management. Further, to 
become competitive in the era, the fourth industrial revolution, firms need different strategy and intellectual capital.

\section{References}

Bingol, D. (2014). Human resource management. Istanbul: Beta Publishing.

Findikci, I. (2012). Human resource management. Istanbul: Alfa Publishing.

Ulucan, A. (2007). Quantitative research. Ankara: Siyasal Publishing.

Uysal, G. (2014). HRM and quantitatives: Decision tree and vector analysis in HRM theory. Chinese Business Review, 13(6), 382-387.

Uysal, G. (2015). Simplex of HR: Talent management with simplex methodology. Chinese Business Review, 14(2), 87-93. 